\title{
Re-habitar - translating Gary Snyder into Portuguese
}

\author{
Luci Collin Lavalle
}

The fact that Gary Snyder is practically unknown in Brazil has always worried me. Differently from some other North-American poets such as, for example, Sylvia Plath, Charles Bukowski and Robert Creeley, whose works are already published in Portuguese, Snyder is practically nonexistent in our editorial market and remains very little studied in Brazilian academic circles. This shows a lamentable absence of serious interest in an internationally recognized writer, who began to be published almost fifty years ago, and whose literary reputation was already well established in the 1970's.'

An intense interest in reversing the lack of readership of Snyder's work in Brazil - knowing that some other people here, who deeply admire Snyder, shared this interest with me - has motivated me to start planning a more elaborate translation project which could introduce the poet to a wider circle. In June 2004 I started drafting an anthology of Snyder's work which would, naturally, include poems and essays. At first I thought of about forty-five poems and eight essays, and my modest intention was to finish the translations and then submit them to publishers. So, I sent a description of this initial project to Snyder and he, with his 
usual generosity, immediately prompted to answer the eventual questions I could have regarding the texts in the course of the translation process. By December, when I had already developed some of the translations, Snyder forwarded me an e-mail he had received from the Brazilian editor Sérgio Cohn (Azougue Editorial, Rio de Janeiro) who had the intention of publishing Snyder's work in Portuguese. What a surprise! We then started "a three-way conversation" (quoting Snyder) comparing my project to Cohn's and, after some arrangements, we were in agreement about the definite translation project which would comprise almost 60 poems from No Nature (New York: Pantheon, 1992) plus 9 essays from $A$ Place in Space (Washington DC: Counterpoint, 1995). The anthology, scheduled to be published in June 2005, is entitled Re-habitar-poemas e ensaios.

As for the discussion of some more specific topics concerning the translation of Snyder into the Portuguese language for Brazilian readers, one cannot disregard the cultural implications and challenges which accompany the whole translation process. In this context, the main problematic issue is possibly how to deal with the numerous references to Amerindian and Oriental cultures/ mythologies, together with the many autobiographical references.

Part of this problem was naturally solved by the addition of some 'Notes to the texts', which explain uses and meanings in the most obscure or hard-to-translate references. When necessary, in these Notes I have quoted parts of the explanations Snyder himself sent to me in our correspondence thus elucidating terms, expressions or even the genesis and content of some poems (or parts of them). ${ }^{2}$ Also of fundamental help for the translations was the small and unpublished book, Questions \& Answers, which Snyder organized in 1994-95 with replies to Mr. Hisao Kanaseki, who translated No Nature into Japanese. Snyder sent this precious material to me at the very beginning of my project. Besides, to contrast translation choices, I have consulted two other translations of Snyder's work: 
La mente salvaje - poemas y ensaios (Madrid: Ediciones Árdora, 2000, N. Fernándes, ed.) translated by Nacho Fernándes, Miguel A. Bernat, José Luis Regojo and John Good, and L'Isola della tartaruga - poesie e saggi (Italy: Stampa Alternativa, 2004, M. Baraghini, ed.) organized and translated by Chiara D'Ottavi.

In terms of form and structure Snyder's poems, with a few exceptions, are not too difficult to translate; likewise, in terms of sound effects (alliteration, assonance, internal rhymes) the level of difficulty is not problematical. But in terms of vocabulary, one has to be careful with many terms because, despite the fact that we do have corresponding words in Portuguese, they are unfamiliar to Brazilians, do not belong to the colloquial vocabulary, and their use could lead to vague references and not very effective results. Some of the difficult areas I worked with are as follows:

a) Flora and fauna references: waterdog, ground squirrel, cottontail, white tail, swift, elk, golden plover, Artic tern, juncos, robins, manzanita, alpine fir, calochortus, Indian paintbrush, grass bamboo.

b) Geographical/regional references: Shuksan, Sourdough, Mt. Baker, Han River, Thunder Creek, Skagit, Dodger Point, Elwa, Goldie, Queets, Siuslaw Forest, Shokoku-ii, Lake Biwa, Uintah Mountains, Sierra Matterhorn, Tyler Road, Poorman Creek.

c) Religious terms and terms related to mythic practices: sanzen, shukuza, saiza, kinhin, shoji, hondo, Marici, striped boys.

d) Professions or activities: Government Trapper, forest lookout, singlejack miner, deckhand.

e) Specific or technical terms: headwall, smoke hole, riprap, a fill-in, green-chain, log dogs, Sharp's repeating rifle.

f) Foreign terms: yukata, vaira, swami, futon, kiva, mattake, Heian, ryokan, Yugao, Yase, Daitoku-ji, Nansen, Jizo, jiki, tipi, bikkhu, swami. 
g) Obscure syntactical structures, unusual word formation or slangs: gypos, sun-facing light changing leaf, soogy (as a verb), pray tell, under the skin, call the shots, sure-foot trails, Cat (caterpillar), bandy-legged bright little dwarf, two-bit caps, rotten tilted-over over-heavy heads, bellywarmer, smooth-skinned.

h) Snyderian peculiarities: Dyonysius of the Cross (Dionísio de Nazaré), lizzard.

Now we come to the analysis of the poem "Right in the trail" (No Nature, p. 375), whose translation proved to be demanding, especially in terms of keeping its readability, fluency and correct effects. I have made a skeleton draft of the poem to pinpoint what seemed to be the main translation difficulties, and the following terms were, thus, listed:

1) "scats" - The best word to use here would be 'excrementos", but it was too long and too sophisticated for the line. Then, the word I used was a more vulgar one and would correspond much more to 'shit'.

2) "manzanita" - There are neither shrubs nor trees in Brazil that could resemble manzanita. I just kept the term considering three aspects: a) one of the previous poems in the anthology was "Manzanita", so the reader would be already familiarized to the term, b) in one of the essays of the anthology ("The Porous World") there is a detailed explanation of the term, and c) it is not difficult for a reader of Portuguese to associate the word we use to apple ("maçã") and to its diminutive form (even in Spanish, the sonority keeps a certain proximity) "maçãzinha", "maçãzita", "manzanita", d) the term is an essential reference to the poem's setting and could never be omitted.

3) "Young girl in the story" - Which girl? Brazilian readers know no story about a girl who married a Bear. They are not even familiar with bears. 
4) "bearscats" - I had to use "excrementos de urso"; no other good word for this.

5) "blueberries" - Once more, the situation is that there are no blueberries in Brazil. The possible words which could be used were: "mirtilo", "vacínio", "uva do monte", "uva ursi" (bearberry), none of them colloquial terms. My first choice was to simplify and say "frutinhos" ("small fruits"), a word that would sound even ironic. But at last I chose "mirtilo", yet doubting whether Brazilian readers would infer that it is a berry or a small fruit; my deliberate choice was motivated by the intention to reinforce the setting as typically North-American, through the use of a not very well-known word.

6) "Big Brown Ones" - For a Brazilian reader a literal translation "Os Grandes Marrons" would be calamitous and could spoil the irony about the Bears. We have no bears here, not even other animals which could, somehow, resemble them. In mythological terms, the only popular figure in our country that could bring some possible similarities to the story of the girl marrying a bear involves another animal, a sort of dolphin named "Boto". Even so, the two stories are very different. Thus, I had to use a word that the reader could identify with an animal: "pardo" and the result was "Grandes Pardos".

7) "berrying" - This form does not exist in Portuguese; the verb (pick up, collect) should be followed by the fruit's name ("pick blueberries"). Among the possibilities were "colher bagas", "coIher mirtilo" or "colher frutos" and I decided to use the last because of the double meaning of "frutos" ("fruits") in Portuguese, a word that could also lead to the idea of "babies" or "having babies", the fruits of the relation between the girl and the Bear to be mentioned in the following lines of the poem.

8) "green salmon"- Snyder had to help me with the word "green". My first impulse (Shame on me!) was to think about the adjective as referring to the fish's color. But I could not find any green salmon. The salmon is a fish that does not exist in our country, 
by the way, so I had to research the topic in encyclopedias. There were blue, blueback, black, red, silver salmon but green... Then Snyder explained it to me: "In the way English is used by native Americans on the North Coast, 'green' means 'fresh' - that is, unsmoked and unsalted".

9) "to cry" - Was it "cry out", "shout", "yell", or "weep". Snyder said it is "weep".

10) "in letters" - In missives or in the literary culture? Snyder explained that in this sentence he is playing on a Chinese phrase about Zen teachings: "not taught in letters, a direct transmission from mind to mind".

11) "Great One" - In this expression the only solution was to add words that could guide the reader to the idea of the mythical creature. So, I translated it as "Grande Ursa Mãe", adding "Bear" ("Ursa") and "Mother" ("Mãe") to assure that the reference was to the mother goddess.

These were the solutions I reached in my translation of the poem. As for the other solutions, in the whole anthology, one never knows whether they are as effective as the translator thought they would be. Anyhow, this is my contribution to try to make Snyder's poetry and thought live in the Portuguese language and culture. Translating Gary Snyder is a wonderful experience, which was, for me, a natural extension of all the pleasure of reading his work and of the emotion of distinguishing in it one of the deepest expressions of essential poetry in contemporary literature. 
Here it is, near the house,

A big pile, fat scats,

Studded with those deep red

Smooth-skinned manzanita berries,

Such a pile! Such droppings,

Awesome. And I saw how

The young girl in the story,

Had good cause to comment

On the bearscats she found while

Picking blueberries with her friends.

She laughed at them

Or maybe with them, jumped over them

(Bad luck!), and is reported

To have said "wide anus!"

To amuse or annoy the Big Brown Ones

Who are listening, of course.

They say the ladies

Have always gone berrying

And they all join together

To go out for the herring spawn,

Or to clean green salmon.

And that big set of lessons

On what bears really want,

Was brought back by the girl

Who made those comments: 
She was taken on a year-long excursion

Deep in the mountains,

Through the tangled deadfalls,

Down into the den.

She had some pretty children by a

Young and handsome Bear.

Now I'm on the dirt

Looking at these scats

And I want to cry not knowing why

At the honor and the humor

Of coming on this sign

That is not found in books

Or transmitted in letters,

And is for women just as much as men,

A shining message for all species,

A glimpse at the Trace

Of the Great One's passing,

With a peek into her whole wild system -

And what was going on last week,

(Mostly still manzanita) -

Dear Bear: do stay around. Be good.

And though I know

It won't help to say this,

Chew your food. 


\section{BEM NO RASTRO}

Tá aí, perto da casa,

Um monte grande e gordo de bosta

Salpicada daquelas bagas vermelho vivo

E sedosas da manzanita,

Que monte! Que esterco

Espantoso. Então eu vi que

A garota da história

Tinha mesmo motivo pra falar

Dos excrementos de urso que achou quando

Colhia mirtilo com as amigas.

Ela riu deles

Ou talvez com eles, pulou por cima deles

(Dá azar!) e conta-se

Que ainda disse "ânus enorme!"

Pra divertir ou provocar os Grandes Pardos

Que estão escutando, claro.

Eles dizem que as moças

Sempre foram colher frutos

E que todos eles se reúnem

Pra assistir à desova do arenque

Ou pra apanhar salmão fresco.

E aquela longa série de lições

Sobre o que os ursos de fato desejam

Foi relembrada pela garota

Que fez os tais comentários: 
Ela foi levada, por um ano, numa excursão

Lá pelas montanhas remotas,

Por emaranhados de fatais armadilhas

Toca abaixo.

Ela teve umas crianças bonitas com um

Urso jovem e formoso.

Agora estou na sujeira

Olhando pra estes excrementos

E quero chorar sem saber por que

À honra e à graça

De ter me deparado com este sinal

Que não se encontra nos livros

Nem é transmitido na literatura,

E existe pras mulheres tanto quanto pros homens,

Uma mensagem clara pra todas as espécies,

Um vislumbre do Traço

Da passagem da Grande Ursa Mãe

Com uma espiada em todo seu sistema selvagem -

E no que aconteceu semana passada,

(Principalmente, ainda, manzanita) -

Querido Urso: fique por perto. Seja bom.

$E$, mesmo que eu saiba

Que não adianta dizer isto,

\section{Mastigue a comida.}




\section{SOBRE A TRADUTORA}

Luci Collin, doutora em Letras pela USP, é professora de Literaturas de Língua Inglesa na UFPR onde também é Coordenadora do Núcleo de Tradução. Tem nove livros publicados (contos e poesia) e participa de antologias literárias nacionais e internacionais (nos EUA, Alemanha, Uruguai, Argentina e França). Recentemente traduziu Gary Snyder (Rehabitar, RJ: Azougue, 2005) e Jerome Rothenberg (Etnopoesia no Milênio, RJ: Azougue, 2006).

\section{NOTAS}

1 Until 2005, the only available translations of Snyder's poems or essays in Brazil were very scarce. There were, basically, some poems in the anthology Quingumbo - Nova poesia norte-americana (SP: Escrita, 1980) and the essay book Old Ways, published under the title Velhos Tempos (PAlegre: L\&PM, 1984, translated by Ciro Barroso). These two books are out of print. And the only noteworthy study on the writer was published in the literary magazine Medusa (SP: lluminuras, n. 02, 1998/99, R. Corona, ed.) in an issue that presented some poems (translated by Maurício A. Mendonça, Ricardo Corona, Rodrigo G. Lopes and myself), an interview with Snyder, and also an essay on his poetics (both my contributions).

2 I have been exchanging messages with Gary Snyder since 1992, when I started researching on the poet to write my Master dissertation "The Quest Motif in Snyder's The Back Country" (UFPR, 1994). 